\title{
To Study the Biochemical Markers for the Prediction of Fistula Formation after Pancreatic Resection Surgery in the Post Operative Period
}

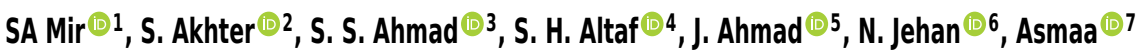 \\ ${ }^{1}$ MD, Pathology, SKIIMS, Soura, Srinagar, Jammu and Kashmir, India, ${ }^{2}$ PG Scholar, Department of Surgery, Govt. Medical College, Karan Nagar, Srinagar, India, \\ ${ }^{3}$ Associate Professor, Department of Surgery, World College of Medical Sciences and Hospital, Gurwar, Jhajjar, Haryana, India, ${ }^{4}$ Medical Officer, Department of Surgery, \\ World College of Medical Sciences and Hospital, Gurwar, Jhajjar, Haryana, India, ${ }^{5}$ Associate Professor, Department of Surgery, Govt. Medical College, Karan Nagar, \\ Srinagar, India, ${ }^{6}$ Associate Professor, Department of Surgery, Govt. Medical College, Karan Nagar, Srinagar, India, ${ }^{7}$ Associate Professor, Department of Surgery, Govt. \\ Medical College, Karan Nagar, Srinagar, India.
}

\section{Abstract}

Background: To study and assess the potential laboratory biomarkers for foreseeing postoperative pancreatic fistula (POPF) after pancreatic resection medical procedures. Subjects and Methods: 64 patients were studied from Jan 2008 to Dec 2018. All patients undergoing Pancreatic resection surgeries like Pancreaticoduodenectomy (PD), distal Pancreatectomy (DP) for tumors of the periampullary region, Pancreatic body or chronic pancreatitis Clinical data of the patients, surgical approach, pancreatic parenchymal tissue consistency, histopathology of the specimen, white blood cell count and blood amylase levels tube Drain fluid amylase were recorded and analyzed. Correlations between these parameters and postoperative pancreatic fistula (POPF) were assessed. Results : 22 out of the $64(34.37 \%)$ patients developed POPF. The fistula was graded according to the ISPG classification. It was Grade An of every $10(45.45 \%)$ patients, grade B in $8(36.36 \%)$, and grade C in $4(18.18 \%)$,.On univariate and multivariate strategic relapse investigations, higher amylase levels in the stomach waste liquid on a postoperative day (POD) 1 and higher serum amylase levels on POD4 indicated a critical relationship with fistula arrangement in the post-operation period (POPF) (P $<0.05)$. On ROC (recipient working trademark bend) examination, amylase cut-off degree of $2270.67 \mathrm{U} / \mathrm{L}$ in the stomach waste liquid was related with a $76.6 \%$ affectability and $82 \%$ particularity [area under the bend (AUC): $0.844 ; \mathrm{P}=0.009$ ]. A cut-off serum amylase level of 53.2 U/L was related with a $74.6 \%$ affectability and $72.9 \%$ explicitness (AUC: $0.784 ; \mathrm{P}=0.05$ ). Conclusion: Post-operative channel liquid amylase levels on day 1 and serum amylase level on day 4 speak to interesting biomarkers related to POPF improvement after the pancreatic medical procedure.

Keywords: Pancreatic fistula, Pancreaticoduodenectomy

Corresponding Author: S. S. Ahmad, Associate Professor, Department of Surgery, World College of Medical Sciences and Hospital, Gurwar, Jhajjar, Haryana, India.

E-mail: drahmads102@gmail.com

Received: 04 September

Revised: 01 November 2020

Accepted: 10 November 2020

Published: 30 December 2020

\section{Introduction}

Pancreaticoduodenectomy (PD) is a typical employable methodology for the treatment of different dangerous infections of the distal biliary pipe, the head of the pancreas, and the peri-ampullar district. It is an extremely perplexing surgery conveying a critical dreariness and mortality. PD is related with significant perioperative mortality $(2 \%-5 \%$ even in highvolume focuses) and bleakness (30\%-50\%). ${ }^{[1,2]}$ Postoperative pancreatic fistula (POPF) is one of the main complexities of the method of $\mathrm{PD}$; detailed occurrence rates range from $2 \%$ to $25 \%$. [3] This confusion may additionally prompt intra stomach draining boil development which expands the expense and emergency clinic remain of the patients. ${ }^{[3,4]}$ POPF and other PD-related complexities are as yet uncontrolled postoperatively in spite of the improvement of more current strategies of pancreatic gut anastomosis. ${ }^{[5]}$ Various pre-usable and intraemployable components, for example, preoperative jaundice Fatty pancreas and lower measurement of the pancreatic channel, are related with higher paces of POPF; in any case, these elements are not dependable indicators of POPF. ${ }^{[6,7]}$ Biochemical markers in serum and waste liquid may mirror the infection movement, and it is exceptionally critical to research their connection with clinical attributes and their expected incentive as indicators of fistula danger in post-operation 
period POPF. In this examination, we explore to recognize possible indicators of POPF improvement, which may help enhance the treatment of these patients in clinical practice.

\section{Subjects and Methods}

64 patients were tentatively remembered for this investigation. Preoperative, Intraoperative and postoperative information was gathered for every patient. Preoperative factors of interest included age, sex, history of diabetes, jaundice, serum protein levels Intraoperative factors included pancreatic surface/consistency, breadth of pancreatic pipe, and the procedure utilized for pancreatic anastomosis. Postoperative information included histopathology of the example, tube channel liquid volume, and post usable confusions, for example, intra stomach draining, intense pancreatitis, deferred gastric exhausting (DGE), pancreatic and biliary fistula [Table 1]. The seriousness of POPF has delegated grade A, B, or $\mathrm{C}$, as characterized by the International Study Group of Pancreatic Fistula. ${ }^{[8]}$ Composed educated assent was acquired from all patients. Postoperative serological and biochemical investigations along with the surgical outcome were recorded.

\section{Procedure}

48 patients underwent Pancreaticoduodenectomy (Whipple's procedure, Six patients were operated on for chronic pancreatitis and 10 patients had distal pancreatic resections. Pancreatojejunostomy was performed by the same surgeon in all patients as follows. A retrocolic jejunal limb was brought into the lesser sac through a window in the transverse colon, an end to side pancreatic-jejunal anastomosis was fashioned in two layers; a duct to mucosa anastomosis was made using PDS interrupted sutures. Abdominal drains two in number were used; one without suction was kept in a subhepatic location, the second adjacent to the pancreatic anastomosis A single drain was used for patients undergoing distal Pancreatectomy DP and was placed adjacent to the pancreatic stump. The drain withdrawal was influenced by levels of amylase recorded postoperatively, the color of the abdominal fluid and the general clinical condition of the patient. Broad-spectrum antibiotics were used in the intial period of $72-96 \mathrm{hrs}$. The upper limit of the reference range of amylase in our laboratory was $100 \mathrm{IU} / \mathrm{L}$.

\section{Statistical Analysis}

Data were analyzed on IBM SPSS 22. Receiver operating characteristic (ROC) curve analysis was performed to assess the sensitivity, specificity, positive predictive value (PPV), and negative predictive value (NPV) of the identified variables. A $P$ value of $<0.05$ was considered as significant. Univariate and

\begin{tabular}{|ll|}
\hline Table 1: Complications & Definition \\
\hline $\begin{array}{l}\text { Complication } \\
\text { Pancreatic Fistula POPF }\end{array}$ & $\begin{array}{l}\text { Amylase activity of fluid in } \\
\text { the drain is at least three } \\
\text { times the upper limit of nor- } \\
\text { mal on or after postopera- } \\
\text { tive day } 3\end{array}$ \\
\hline $\begin{array}{l}\text { Free fluid in Peritoneum } \\
\text { (Ascites) }\end{array}$ & $\begin{array}{l}>5 \mathrm{~cm} \text { of fluid depth on } \\
\text { USG abdomen }\end{array}$ \\
\hline $\begin{array}{l}\text { Post-op Bleeding Hemor- } \\
\text { rhage }\end{array}$ & $\begin{array}{l}\text { The requirement of }>2 \\
\text { units of whole blood }\end{array}$ \\
\hline Biliary fistula & $\begin{array}{l}\text { Bilious drainage of }>50 \mathrm{ml} \\
\text { post-op }\end{array}$ \\
\hline
\end{tabular}

multivariate analyses were performed to identify factors significantly related to fistula formation POPF.

\section{Results}

Out of 64 patients, $22(34.7 \%)$ created POPF. The seriousness of POPF was delegated grade an of every $10(45.45 \%)$ patients, grade $\mathrm{B}$ in $8(36.36 \%)$ and grade $\mathrm{C}$ in $4(18.18 \%)$ [Table 2]. Division of patients was made into fistulous gatherings (POPF) and non-fistulous gatherings (non-pop gatherings) and afterward looked at the degrees of various boundaries between the two gatherings [Table 3]. On univariate investigation, amylase level in the stomach seepage liquid on postoperation day 1 and serum amylase level on day 1 and day 4 postoperatively was connected with pancreatic fistula arrangement (POPF) $(\mathrm{P}<0.05)$ [Table 4]. Multivariate strategic relapse investigation affirmed that amylase level in stomach seepage liquid on post-operation day 1 and serum amylase level on day 4 were autonomous indicators of POPF [Table 5]. On Receiver Operating Curve (ROC) investigation, a cut-off amylase level of $2365.5 \mathrm{U} / \mathrm{L}$ in the stomach seepage liquid on post-operation day 1 as an indicator of POPF was related with $78.6 \%$ affectability, the particularity of $80 \%, 66.7 \%$ positive prescient worth (PPV) and $88 \%$ negative prescient worth (NPV); $\mathrm{P}=0.009$ ] [Figure 1]. Essentially, a cut-off serum amylase level of $44.2 \mathrm{U} / \mathrm{L}$ on postoperation day 4 was related with a $78.6 \%$ affectability and $70.9 \%$ particularity [AUC: $0.784 ; \mathrm{P}=0.05$; Figure 2]. The explicitness of these affiliations was additionally featured by the perception that neither one of the whites platelet (WBC) tallies nor egg whites levels related with post-operation fistula arrangement POPF advancement.

\section{Discussion}

"Whipple method" for Pancreaticoduodenectomy (PD) for the treatment of threatening tumors in the head of the pancreas 


\begin{tabular}{|lll}
\hline Table 2: Complications & & \\
\hline Complication & $\begin{array}{l}\text { Cases } \\
\mathbf{2 6}\end{array}$ & Incidence \% \\
\hline Post-op Fistula & 22 & 34.37 \\
\hline Grade A & 10 & 45.45 \\
\hline Grade B & 8 & 36.36 \\
\hline Grade C & 4 & 18.18 \\
\hline $\begin{array}{l}\text { Free Fluid in Peritoneal } \\
\text { cavity (Ascites) }\end{array}$ & 6 & 27.27 \\
\hline $\begin{array}{l}\text { Bleeding } \\
\text { Post-op Biliary leak }\end{array}$ & 4 & 18.18 \\
\hline Paralytic ileus & 2 & 9.99 \\
\hline
\end{tabular}

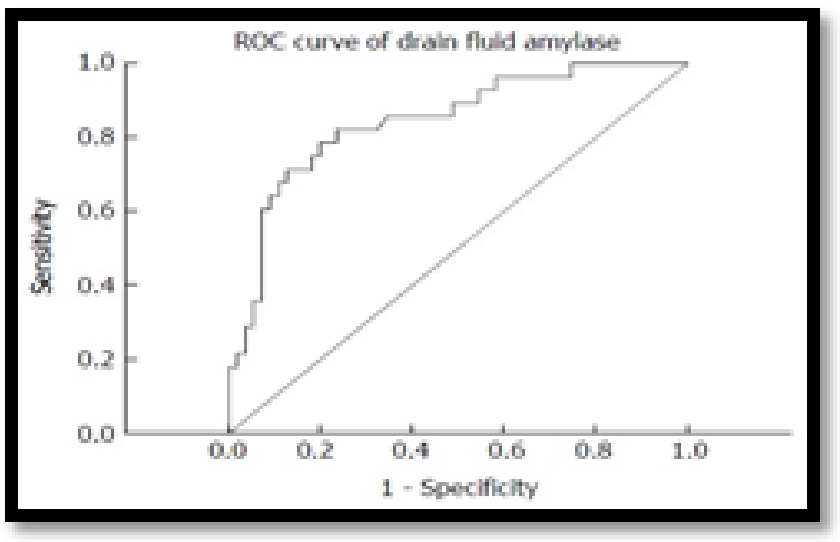

Figure 1: ROC curve analysis of amylase activity in tube drain fluid. 2365.5 U/L was associated with $78.6 \%$ sensitivity, $80 \%$ specificity, $66.7 \%$ positive predictive value and $88 \%$ negative predictive value for risk of fistula formation.

and the peri-ampullar locale is one of the most unpredictable and progressed surgery of fluctuating inconveniences and delayed activity time. ${ }^{[9,10]}$ Postoperative difficulties following PD range from $30 \%-70 \%$, and a death pace of $5 \%$ or all the more even in high-volume centers. ${ }^{[1]}$ POPF represents $2 \%$ $25 \%$ of all entanglements of methodology. ${ }^{[12]}$ More up to date careful methods for Pancreaticojejunostomy like conduit mucosa or pancreatic channel stent implantation have not brought about any significant improvement in diminishing the fistula rates.

As such early discovery of POPF and ideal mediation is imperative to improve careful results. ${ }^{[13-17]}$ Different instruments and procedures have been concentrated to recognize patients who are in danger of the advancement of fistula POPF. This investigation distinguished possible indicators of POPF and the outcomes recommend that cylinder channel liquid amylase

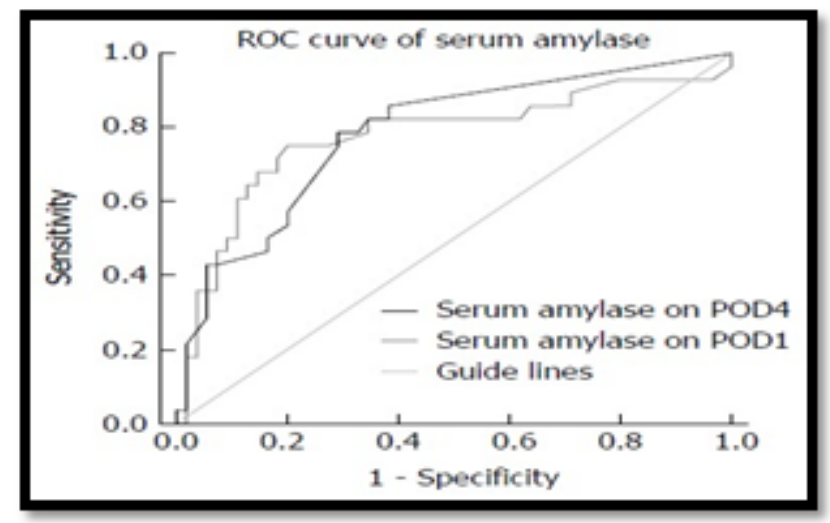

Figure 2: Serum amylase ROC curve analysis activity. Post op day 4 value of $44.2 \mathrm{U} / \mathrm{L}$ on has a $78.6 \%$ sensitivity and $70.9 \%$ specificity for post op fistula risks.

(DFA) levels and serum amylase levels can serve as clinical biomarkers and its measurement is simple and promising. Factors assigned fistula formation include pancreatic parenchymal texture, Pancreatic duct diameter, Histopathology of the specimen and comorbidities associated; ${ }^{[18-23]}$ however, the prescient worth has been demonstrated to be generally poor and conflicting. In the current investigation, we noticed a conspicuous connection between's amylase levels in the cylinder channel liquid on POD1 and the serum amylase level on POD4 with the event of POPF. Recently published data (Popiela et al; Kawai et al, ${ }^{[24-26]}$ show that drainage fluid amylase levels on post-op Day 1 (> $350 \mathrm{U} / \mathrm{L}$ ) predicts post of the fistula with a $79 \%$ specificity and a sensitivity of $100 \%$. A positive prescient estimation of $41 \% \mathrm{PPV}$, and a negative prescient of $100 \%$. The aftereffects of this investigation show that post-operation day 1 amylase level in channel liquid and blood amylase on day 4 could foresee the chance of pancreatic fistula development in the post usable period after pancreatic medical procedure Leukocyte tallies and protein levels (albumen) were not seen to have any relationship with fistula arrangement. ${ }^{[27-29]}$ Our results were consistent with the published reports. A cut-off amylase level in tube drain of 2365.5 was associated with a prediction of fistula formation in $78.6 \%$ and a specificity of $80 \%$; It has a positive predictive value of $66.7 \%$ and a negative predictive value of $88 \%$. Our conclusion from the study is that in patients with the post of pancreatic fistula POPF, increased levels of amylase in tube drain on post-op day 1 comes from the disruption in the pancreatic and bowel anastomosis causing leaks and fistula formation. S Amylase levels in serum on post-op day 4 as high as $100 \mathrm{u} / 1$ have a prediction of fistula formation with a sensitivity of $42.9 \%$ and a specificity of $55 \%$ having a positive predictive value of $75 \%$ with a negative value of $76.1 \%$. Intraoperative and postoperative hypovolemia and compression injury to pancreatic vessels during the 


\begin{tabular}{|c|c|c|c|c|}
\hline Variables & POPF (22) & Non-POPF (42) & $\chi^{2}$ & P Value \\
\hline Patients Age (yrs) & 52.7 & 51.4 & 0.07 & 0.94 \\
\hline $\begin{array}{l}\text { Gender } \\
\text { Male } \\
\text { Female }\end{array}$ & $\begin{array}{l}12(54.5) \\
10(45.5)\end{array}$ & $\begin{array}{l}22(52.38) \\
20(47.61)\end{array}$ & & \\
\hline Operative blood loss (ml) & $325(250-570)$ & $300(200-450)$ & 1.25 & 0.2 \\
\hline $\begin{array}{l}\text { Pancreatic duct diameter } \\
\text { Less than } 3 \mathrm{~mm} \\
\text { More than } 3 \mathrm{~mm}\end{array}$ & $\begin{array}{l}8 \\
14\end{array}$ & $\begin{array}{l}13 \\
29\end{array}$ & 3.18 & 0.13 \\
\hline $\begin{array}{l}\text { Pre-op Jaundice } \\
\text { Yes } \\
\text { No }\end{array}$ & $\begin{array}{l}9 \\
13\end{array}$ & $\begin{array}{l}14 \\
28\end{array}$ & 0.17 & 0.78 \\
\hline $\begin{array}{l}\text { Pre-op Biliary drainage } \\
\text { Yes } \\
\text { No }\end{array}$ & $\begin{array}{l}3 \\
19\end{array}$ & $\begin{array}{l}4 \\
24\end{array}$ & 0.46 & 0.47 \\
\hline $\begin{array}{l}\text { ERC Drainage } \\
\text { External } \\
\text { Internal }\end{array}$ & $\begin{array}{l}8 \\
14\end{array}$ & & 0.28 & 0.78 \\
\hline Procedure time & $270(240-380)$ & $285(235-370)$ & -0.08 & 0.97 \\
\hline Hospital stay (Days) & $15(12-21)$ & $9(7-17)$ & -2.29 & 0.91 \\
\hline $\begin{array}{l}\text { Comorbidity Diabetes } \\
\text { Yes } \\
\text { No }\end{array}$ & $\begin{array}{l}4 \\
18\end{array}$ & $\begin{array}{l}8 \\
34\end{array}$ & 4.29 & 0.89 \\
\hline $\begin{array}{l}\text { Drainage fluid amylase level } \\
\text { on POD1 in U/L }\end{array}$ & $6085(2395-10800)$ & $654(400-972)$ & -4.9 & $<0.001$ \\
\hline $\begin{array}{l}\text { Serum amylase level in } \mathrm{U} / \mathrm{L} \\
\text { Post op } \\
\text { D1 } \\
\text { D4 }\end{array}$ & $\begin{array}{l}340(168-690) \\
40(30-74)\end{array}$ & $\begin{array}{l}100(50-190) \\
30(25-52)\end{array}$ & -5.01 & $<0.00$ \\
\hline $\begin{array}{l}\text { Albumen } \\
\text { D1 } \\
\text { D3 } \\
\text { D5 }\end{array}$ & $\begin{array}{l}2.9(2.5-3.8) \\
3.1(2.9-3.9) \\
3.1(2.8-4.0)\end{array}$ & $\begin{array}{l}3.1(2.4-4.2) \\
3.0(2.8-4.0) \\
3-1(2.7-4.1)\end{array}$ & -0.12 & 0.97 \\
\hline $\begin{array}{l}\text { White Blood Cell Count } \\
\text { (TLC)t } \\
\text { D1 } \\
\text { D3 } \\
\text { D5 }\end{array}$ & $\begin{array}{l}14.7(10.8-18.7) \\
14.90(11.7-18.64) \\
11.99(9.65,15.5)\end{array}$ & $\begin{array}{l}15.4(12.4-18.5) \\
13.5(10.8-16.7) \\
11.2(9.8-14.6)\end{array}$ & $\begin{array}{l}-0.7 \\
-1.12 \\
0.75\end{array}$ & $\begin{array}{l}0.4 \\
0.2 \\
0.6\end{array}$ \\
\hline $\begin{array}{l}\text { Specimen Histopathology } \\
\text { Results } \\
\text { Adenoma Pancreas } \\
\text { PeriampullaryCa } \\
\text { CholingioCa } \\
\text { Others }\end{array}$ & $\begin{array}{l}8 \\
6 \\
4 \\
4\end{array}$ & $\begin{array}{l}18 \\
14 \\
4 \\
6\end{array}$ & & \\
\hline
\end{tabular}

surgery cause ischemic injury to pancreatic tissues which leads to elevation of serum enzyme amylase. ${ }^{[30,31]}$ No factually huge relationship was seen between serum amylase level in post- operation day 1 and pancreatic spillage, and no connection was found between serum amylase levels on day 4 mirrors the foundation of the pancreatic anastomosis. The disruptive effect of 


\begin{tabular}{|c|c|c|c|c|c|}
\hline Variabales & $\beta$ & SE & Wald $\chi^{2}$ & $\mathbf{0 R}$ & "P "value \\
\hline Patient Age (yrs) & 0.023 & 0.03 & 0.39 & 1.02 & 0.52 \\
\hline Gender; female/male & -0.58 & 0.5 & 0.5 & 0.56 & 0.27 \\
\hline Operative Blood loss in $\mathrm{mL}$ & 0.00 & 0.01 & 1.35 & 1.00 & 0.61 \\
\hline Duct diameter, & 0.83 & 0.4 & 3.13 & 0.45 & 0.07 \\
\hline \multicolumn{6}{|l|}{ More than $3 \mathrm{~mm} \mathrm{Or}<3 \mathrm{~mm}$} \\
\hline Plasma protein low, yes/no & 0.17 & 0.7 & 0.16 & 1.19 & 0.77 \\
\hline Jaundice Relieved, yes/no & 0.75 & 0.5 & 1.01 & 2.12 & 0.43 \\
\hline Comorbidity of Jaundice, yes/no & 0.10 & 0.4 & 0.04 & 1.11 & 0.82 \\
\hline Drainage of Pancreas & 0.23 & 0.4 & 0.28 & 1.26 & 0.56 \\
\hline Comorbidity; Diabetes, yes/no & 21.9 & 26450.8 & 0.000 & 3.67 & 0.99 \\
\hline $\begin{array}{l}\text { Histopathology result, Ampullary } \\
\text { carcinoma }\end{array}$ & 0.24 & 0.1 & 1.74 & 2.34 & 0.18 \\
\hline $\begin{array}{l}\text { Pancreatic } \\
\text { noma/cholangiocarcinoma }\end{array}$ & & & & & \\
\hline Intraoperative Time in min & 0.00 & 0.01 & 0.008 & 1.00 & 0.98 \\
\hline $\begin{array}{l}\text { Amylase levels in drain fluid, POD1 } \\
>5000 \mathrm{U} / \mathrm{L}\end{array}$ & 0.00 & 0.00 & 8.93 & 1.00 & 0.001 \\
\hline $\begin{array}{l}\text { Blood amylase level } \\
\text { Day } 1>140 \mathrm{U} / \mathrm{L} \\
\text { Day } 4>140 \mathrm{U} / \mathrm{L}\end{array}$ & $\begin{array}{l}0.004 \\
0.013\end{array}$ & $\begin{array}{l}0.01 \\
0.03\end{array}$ & $\begin{array}{l}6.94 \\
7.75\end{array}$ & $\begin{array}{l}1.00 \\
1.01\end{array}$ & $\begin{array}{l}0.002 \\
0.005\end{array}$ \\
\hline $\begin{array}{l}\text { Post op albumin } \\
\text { Day } 1 \\
\text { Day } 3 \\
\text { Day } 5\end{array}$ & $\begin{array}{l}0.00 \\
-0.006 \\
-0.023\end{array}$ & $\begin{array}{l}0.04 \\
0.04 \\
0.04\end{array}$ & $\begin{array}{l}0.00 \\
0.02 \\
0.27\end{array}$ & $\begin{array}{l}1.00 \\
0.99 \\
0.98\end{array}$ & $\begin{array}{l}0.99 \\
0.08 \\
0.58\end{array}$ \\
\hline $\begin{array}{l}\text { Post-op TLC count } \\
\text { Day } 1 \\
\text { Day } 3 \\
\text { Day } 5\end{array}$ & $\begin{array}{l}0.00 \\
0.00 \\
0.00\end{array}$ & $\begin{array}{l}0.00 \\
0.00 \\
0.00\end{array}$ & $\begin{array}{l}1.15 \\
1.25 \\
2.20\end{array}$ & $\begin{array}{l}1.00 \\
1.00 \\
1.00\end{array}$ & $\begin{array}{l}0.28 \\
0.25 \\
0.15\end{array}$ \\
\hline
\end{tabular}

Table 5: Results of Multivariate Logistic Regression Analysis Showing Risk Factors for Postoperative Pancreatic Fistula

\begin{tabular}{llllll}
\hline Parameter & $\beta$ & Se & Wald $\chi^{2}$ & Or & P value \\
\hline Post op amylase level, Day $1>5000$ U/L & 0.000 & 0.000 & 6.27 & 1.000 & 0.009 \\
Post Op Day 1 > 140 U/L & 0.001 & 0.002 & 0.34 & 1.001 & 0.624 \\
\hline Levels on Day 4 > 140 U/L & 0.007 & 0.004 & 3.82 & 1.008 & 0.050 \\
\hline
\end{tabular}

pancreatic enzymes on the anastomotic site and the vasculature increases the absorption of amylase causing the rise in serum amylase levels. Therefore day 4 blood amylase level is of sure prescient incentive for the event of post-operation fistula. In our examination, we found that amylase movement in waste liquid on day 1 and serum amylase action on day 4 could precisely foresee post of pancreatic fistula POPF. Protein levels (albumen) leukocyte counts did not show a significant prediction for fist ululation. Amylase levels in tube drain on post-op day 1 and blood amylase level on day 4 is a comparatively easy and economical method in clinical practice. This study supports the use of tube drain amylase levels to predict pancreatic fistula formation. This may help for timely interventions (percutaneous drainage/exploration), increased hospitalization prolonged use of antibiotics and octreotide.

Treatments, that may help forestall POPF and consider convenient danger correspondence to the patient. It is additionally another method in the preparing did in our clinical focus. 


\section{Conclusion}

Post-operative channel liquid amylase levels on day 1 and serum amylase level on day 4 speak to interesting biomarkers related to POPF improvement after the pancreatic medical procedure,

\section{References}

1. Kastenberg ZJ, Morton JM, Visser BC, Norton JA, Poultsides GA. Hospital readmission after a pancreaticoduodenectomy: an emerging quality metric? HPB. 2013;15(2):142-148. Available from: https://dx.doi.org/10.1111/j.1477-2574.2012.00563.x.

2. Vollmer CM, Sanchez N, Gondek S, Mcauliffe J, Kent TS, Christein JD, et al. Pancreatic Surgery Mortality Study Group. A root-cause analysis of mortality following major pancreatectomy. J Gastrointest Surg. 2012;16(1):89-103. Available from: https://doi.org/10.1007/s11605-011-1753-x.

3. Ahmad SA, Edwards MJ, Sutton JM, Grewal SS, Hanseman DJ, Maithel SK, et al. Factors Influencing Readmission After Pancreaticoduodenectomy. Annals of Surgery. 2012;256(3):529-537. Available from: https://dx.doi.org/10. 1097/sla.0b013e318265ef0b.

4. Gulbinas A, Barauskas G, Pundzius J. Preoperative stratification of pancreas-related morbidity after the Whipple procedure. Int Surg. 2004;89(1):39-45.

5. Büchler MW, Friess H, Wagner M, Kulli C, Wagener V, Z'graggen K. Pancreatic fistula after pancreatic head resection. Br J Surg. 2000;87(7):883-889. Available from: https://dx.doi. org/10.1046/j.1365-2168.2000.01465.x.

6. Kingsnorth AN. Duct to mucosa isolated Roux loop pancreaticojejunostomy as an improved anastomosis after resection of the pancreas. Surg Gynecol Obstet. 1989;169(5):451-453.

7. Yeo CJ, Cameron JL, Maher MM, Sauter PK, Zahurak ML, Talamini MA, et al. A prospective randomized trial of pancreaticogastrostomy versus pancreaticojejunostomy after pancreaticoduodenectomy. Ann Surg. 1995;222(4):580 588. Available from: https://doi.org/10.1097/00000658$199510000-00014$.

8. Bassi C, Dervenis C, Butturini G, Fingerhut A, Yeo C, Izbicki J. International Study Group on Pancreatic Fistula Definition. Postoperative pancreatic fistula: an international study group (ISGPF) definition. Surgery. 2005;138(1):8-13. Available from: https://doi.org/10.1016/j.surg.2005.05.001.

9. Wellner UF, Kayser G, Lapshyn H, Sick O, Makowiec F, Höppner J. A simple scoring system based on clinical factors related to pancreatic texture predicts postoperative pancreatic fistula preoperatively. HPB. 2010;12(10):696-702. Available from: https://dx.doi.org/10.1111/j.1477-2574.2010.00239.x.

10. Kleespies A, Albertsmeier M, Obeidat F, Seeliger H, Jauch KW, Bruns CJ. The challenge of pancreatic anastomosis. Langenbecks Arch Surg. 2008;393(4):459-471. Available from: https://dx.doi.org/10.1007/s00423-008-0324-4.

11. Bassi C, Falconi M, Molinari E, Mantovani W, Butturini G, Gumbs AA, et al. Duct-to-mucosa versus end-to-side pancreaticojejunostomy reconstruction after pancreaticoduodenectomy: results of a prospective randomized trial. Surgery.
2003;134(5):766-771. Available from: https://dx.doi.org/10. 1016/s0039-6060(03)00345-3.

12. Whipple AO, Parsons WB, Mullins CR. Teeatment of Carcinoma of the Ampulla of Vater. Ann Surg. 1935;102(4):763779. Available from: https://dx.doi.org/10.1097/00000658193510000-00023.

13. Xiong JJ, Altaf K, Mukherjee R, Huang W, Hu WM, Li A, et al. Systematic review and meta-analysis of outcomes after intraoperative pancreatic duct stent placement during pancreaticoduodenectomy. Br J Surg. 2012;99(8):1050-1061. Available from: https://dx.doi.org/10.1002/bjs.8788.

14. Lillemoe K, Cameron J, Kim M, Campbell K, Sauter P, Coleman J, et al. Does fibrin glue sealant decrease the rate of pancreatic fistula after pancreaticoduodenectomy? Results of a prospective randomized trial. J Gastrointest Surg . 2004;8(7):766-774. Available from: https://dx.doi.org/10. 1016/j.gassur.2004.06.011.

15. Yeo CJ, Cameron JL, Sohn TA, Lillemoe KD, Pitt HA, Talamini MA, et al. Six Hundred Fifty Consecutive Pancreaticoduodenectomies in the 1990s. Ann Surg. 1997;226(3):248260. Available from: https://dx.doi.org/10.1097/00000658199709000-00004.

16. Deoliveira ML, Winter JM, Schafer M, Cunningham SC, Cameron JL, Yeo CJ, et al. Assessment of complications after pancreatic surgery: A novel grading system applied to 633 patients undergoing pancreaticoduodenectomy. Ann Surg. 2006;244(6):937-939. Available from: https://doi.org/ 10.1097/01.sla.0000246856.03918.9a.

17. Lee SE, Yang SH, Jang JY, Kim SW. Pancreatic fistula after pancreaticoduodenectomy: a comparison between the two pancreaticojejunostomy methods for approximating the pancreatic parenchyma to the jejunal seromuscular layer: interrupted vs continuous stitches. World J Gastroenterol. 2007;13(40):5351-5356. Available from: https://doi.org/10. 3748/wjg.v13.i40.5351.

18. Kazanjian KK. Management of Pancreatic Fistulas After Pancreaticoduodenectomy. Arch Surg. 2005;140(9):849849. Available from: https://dx.doi.org/10.1001/archsurg. 140. 9.849 .

19. Veillette G, Dominguez I, Ferrone C, Thayer SP, Mcgrath D, Warshaw AL. Fernández-del Castillo C. Implications and management of pancreatic fistulas following pancreaticoduodenectomy: the Massachusetts General Hospital experience. Arch Surg. 2008;143(5):476-481. Available from: https://doi.org/ 10.1001/archsurg.143.5.476.

20. Cloyd JM, Kastenberg ZJ, Visser BC, Poultsides GA, Norton JA. Postoperative Serum Amylase Predicts Pancreatic Fistula Formation Following Pancreaticoduodenectomy. J Gastrointest Surg. 2014;18(2):348-353. Available from: https://dx.doi.org/ 10.1007/s11605-013-2293-3.

21. Henegouwen MIVB, Wit D, Gulik LTV, Obertop TM, Gouma H, J D. Incidence, risk factors, and treatment of pancreatic leakage after pancreaticoduodenectomy: drainage versus resection of the pancreatic remnant. J Am Coll Surg. 1997;185(1):18-24. Available from: https://doi.org/10.1016/ s1072-7515(97)00007-0.

22. Bassi C, Butturini G, Molinari E, Mascetta G, Salvia R, Falconi M, et al. Pancreatic Fistula Rate after Pancreatic Resection. Dig 
Surg. 2004;21(1):54-59. Available from: https://dx.doi.org/10. $1159 / 000075943$.

23. Sato N, Yamaguchi K, Chijiiwa K, Tanaka M. Risk analysis of pancreatic fistula after pancreatic head resection. Arch Surg. 1998;133(10):1094-1098. Available from: https://doi.org/10. 1001/archsurg.133.10.1094.

24. Popiela T, Kedra B, Sierzega M, Gurda A. Risk factors of pancreatic fistula following pancreaticoduodenectomy for periampullary cancer. Hepatogastroenterology. 2004;51(59):14841488.

25. Kawai M, Tani M, Hirono S, Ina S, Miyazawa M, Yamaue H. How Do We Predict the Clinically Relevant Pancreatic Fistula After Pancreaticoduodenectomy?-An Analysis in 244 Consecutive Patients. World J Surg. 2009;33(12):2670-2678. Available from: https://dx.doi.org/10.1007/s00268-009-02202.

26. Relles DM, Richards NG, Bloom JP, Kennedy EP, Sauter PK, Leiby BE, et al. Serum Blood Urea Nitrogen and Serum Albumin on the First Postoperative Day Predict Pancreatic Fistula and Major Complications After Pancreaticoduodenectomy. J Gastrointest Surg. 2013;17(2):326-331. Available from: https: //dx.doi.org/10.1007/s11605-012-2093-1.

27. Ryan AM, Hearty A, Prichard RS, Cunningham A, Rowley SP, Reynolds JV. Association of Hypoalbuminemia on the First Postoperative Day and Complications Following Esophagectomy. J Gastrointest Surg. 2007;11(10):1355-1360. Available from: https://dx.doi.org/10.1007/s11605-007-0223y.

28. Mahkovic-Hergouth K, Kompan L. Is the replacement of albumin in major abdominal surgery useful? J Clin Anesth. 2011;23(1):42-46. Available from: https://doi.org/10.1016/j. jclinane.2010.06.007.
29. Welsch T, Frommhold K, Hinz U, Weigand MA, Kleeff J, Friess $\mathrm{H}$, et al. Persisting elevation of C-reactive protein after pancreatic resections can indicate developing inflammatory complications. Surgery. 2008;143(1):20-28. Available from: https://dx.doi.org/10.1016/j.surg.2007.06.010.

30. van den Bos R, Taris R, Scheppink B, de Haan L, Verster JC. Salivary cortisol and alpha-amylase levels during an assessment procedure correlate differently with risk-taking measures in male and female police recruits. Front Behav Neurosci. 2014;7:219-219. Available from: https://dx.doi.org/10.3389/ fnbeh.2013.00219.

31. Okano K, Kakinoki K, Suto H, Oshima M, Kashiwagi H, Yamamoto N, et al. Persisting ratio of total amylase output in drain fluid can predict postoperative clinical pancreatic fistula. Journal of Hepato-Biliary-Pancreatic Sciences. 2011;18(6):815-820. Available from: https://dx.doi.org/10. 1007/s00534-011-0393-6.

Copyright: (C) the author(s), 2020. It is an open-access article distributed under the terms of the Creative Commons Attribution License (CC BY 4.0), which permits authors to retain ownership of the copyright for their content, and allow anyone to download, reuse, reprint, modify, distribute and/or copy the content as long as the original authors and source are cited.

How to cite this article: Mir SA, Akhter S, Ahmad SS, Altaf SH, Ahmad J, Jehan N, A. To Study the Biochemical Markers for the Prediction of Fistula Formation after Pancreatic Resection Surgery in the Post Operative Period. Acad. J Surg. 2020;3(2): 33-39.

DOI: dx.doi.org/10.47008/ajs/2020.3.2.9

Source of Support: Nil, Conflict of Interest: None declared. 